\title{
TEACHING DIGITAL CULTURAL HERITAGE AND DIGITAL HUMANITIES THE CURRENT STATE AND PROSPECTS
}

\author{
S. Münster ${ }^{1}$, K. Fritsche ${ }^{1}$, H. Richards-Rissetto ${ }^{2}$, F. Apollonio ${ }^{3}$, B. Aehnlich ${ }^{4}$, V. Schwartze ${ }^{4}$, R. Smolarski ${ }^{1}$ \\ ${ }^{1}$ Digital Humanities, FSU Jena, Germany - sander.muenster@uni-jena.de, katrin.fritsche@uni-jena.de, rene.smolarski@uni-jena.de \\ ${ }^{2}$ School of Global Integrative Studies \& Center for Digital Research in the Humanities, University of Nebraska-Lincoln, USA - \\ richards-rissetto@unl.edu \\ ${ }^{3}$ Dipartimento di Architettura, Alma Mater Studiorum - Università di Bologna, Bologna, Italy - fabrizio.apollonio@unibo.it \\ ${ }^{4}$ Michael Stifel Center, Jena FSU Jena, Germany - barbara.aehnlich@uni-jena.de, volker.schwartze@uni-jena.de
}

KEY WORDS: Digital Humanities, Digital Cultural Heritage, Challenges, Education, Teaching

\section{ABSTRACT:}

Digital literacy and technology education has gained much relevance in humanities and heritage related disciplines during the recent decades. Against this background, the purpose of this article is to examine the current state of educational programs in digital cultural heritage and related disciplines primarily in Europe with supplemental information from the US. A further aim is to highlight core topics, challenges, and demands, and to show innovative formats and prospects.

\section{INTRODUCTION}

Digital literacy and technologies are becoming increasingly important for researchers in humanities and heritage related disciplines. Scholars have identified the development of combined digital and humanities skills as a critical challenge (Münster, 2019) for the cultural heritage sector, and this is a key issue in the European Commission's Digital Cultural Heritage (DCH) priorities for the 2020s (European Commission, 2017, 2019b).

Cultural heritage refers to traces and expressions from the past that have lasting value in contemporary society (cf. UNESCO, 1989). Cultural heritage traditionally focuses on tangible objects, but a broader understanding that incorporates intangible heritage and computer-based material has gained importance over the last decade. Digital heritage, technically intangible, comprises resources of human knowledge or expression (e.g., cultural, educational, scientific) as well as cultural heritage materials including texts, images etc. which are created digitally or converted into digital form (UNESCO, 2018).

Although there are many university programs and courses focusing on DHC, there is no comprehensive overview of programs. One reason may be that many programs are driven by traditional fields such as digital archaeology, digital curation or digital conservation as well as related areas as digital humanities (DH) (cf. Münster et al., 2019). Besides higher education, there is a wide spectrum of vocational courses (the EU Codeweek program, DARIAH Teach, PARTHENOS, DHSI, ${ }^{*}$ etc.) and frameworks for training and qualification activities (within ERASMUS+, $\operatorname{COST}^{\dagger}$ etc.).

The purpose of this article is to (a) examine the current state of educational programs, especially at universities in digital heritage and related disciplines to (b) learn about core topics, challenges, and demands. Another objective is to show (c) innovative formats to enable teaching of digital heritage skills. Therefore, the article includes four sections:

(A) A sketch of a framework and conditions for DCH education.

(B) A discussion of core curricula and competencies in the field of digital heritage that are widely missing in reference to the

\footnotetext{
" https://teach.dariah.eu, https://www.parthenos-project.eu,
} https://codeweek.eu/, https://dhsi.org/, June 23, 2021.
$\mathrm{DH}$, which have developed comprehensive core curricula at various levels.

(C) Best practice examples in teaching skills related to $\mathrm{DCH}$, including innovative formats, and a discussion of didactic aspects.

(D) Future prospects include vocational training and lifelong learning in the field of DCH so that scholars and staff acquire and maintain relevant skills and enabling a wide public to acquire digital competencies via cultural heritage as application scenarios - e.g., via citizen science or crowdsourced repositories and applications.

\section{FRAMEWORK CONDITIONS FOR DIGITAL HERITAGE EDUCATION}

In this section, we set the stage for our discussion with an overview of competency frameworks and educational structures framing the teaching and learning of DCH.

\section{Competency Centers}

Competency centers are hubs for servicing cultural heritage, for example, by offering technical support, infrastructure, and training. Competency centers have been well established for DH (cf. Risam, 2016) and DCH on national levels, e.g. in Sweden (c.f., Gottlieb, 2012) for more than a decade. Currently, the concept of competency centers is under development to cover the European level with regards to heritage conservation and heritage (European Commission, 2021).

\section{Competency Frameworks}

Competency frameworks provide agreed definitions, descriptions, and implementation methods according to the demands, standards, and guidelines of specific sectors (Corr et al., 2019). The DigComp framework (European Commission, 2019a) takes into account digital literacy as a future and critical skill for citizens. Digital literacy skills include (but are not limited to) information and data literacy, communication, and collaboration, digital content creation, data security, and problem solving. Additional competencies are hardware and software operations and career-related skills. To create digitally literate citizens, it is necessary to train educators. Some frameworks that include recommendations for educators exist. For example, a digital literacy framework (JISC, 2014) that addresses university

${ }^{\dagger}$ https://www.erasmusplus.eu/, https://www.cost.eu/, June 23, 2021. 
educators in English-speaking countries covers media literacy, communications and collaboration, career and identity management, ICT literacy, learning skills, formal and informal digital scholarship, and information literacy. (Eichhorn et al., 2017) further divide media literacy into operating, application and informing, or researching via digital channels. The DigCompEdu (Redecker, 2017) thematizes explicit requirements for future educators including professional engagement, digital resources, teaching and learning, assessment, empowering learners, and facilitating learners' digital competency. Digital competency is critical for operating digital tools in teaching and research, so educators need the digital skills to evoke these competencies in learners. The European e-Competence Framework (European Committee for Standardization, 2014) focuses on digital skills and competencies required for professional applications. For 40 job profiles it defines specific competency areas, such as content creation and security. As for cultural heritage, required competencies were investigated during the European Year of Cultural Heritage in 2018 (Corr et al., 2019). The main outcome was a SWOT analysis on member state levels (Roche et al., 2019).

\section{Educational Programs}

Globally, DCH is an emerging field. Discourse about its role and position within the humanities is ongoing, and educational programs for DCH vary on international, national, and local levels. In Italy, for example, the DCH educational program is part of the legislative context that governs bachelor and master's degree courses (Italian Ministry of Universities and Scientific and Technology Research, 2004). Somewhat unique, the objective of this program is to train a new generation of professionals that are aware and capable of supporting the digitalization process in public administration (Italian Republic President, 2005). Within that context, in 2011, training became mandatory for all work promoted and financed by the Ministry of Cultural Heritage, especially for digital interventions for protected objects,(Italian Republic President, 2005, esp. art. 42). The purpose was to simplify documentation and share the process with the Superintendence, entrusted with collecting documentation on restoration and consolidation activities (Directorate-General for Landscape, 2011).

The courses provided by the LM-43 class* of master's degrees in computer methodologies for humanities disciplines (in Italy) offer the methodological knowledge necessary for the use of IT tools in the humanities. Graduates f must have basic training in the humanities (linguistic, philological and literary, or historical and philosophical); in cultural heritage; in the arts, music, and entertainment; or in communication sciences. They must also be able to tackle problems of knowledge representation and possess the theoretical, methodological, and technical tools relating to the computer processing of texts, images, sound, and video in a humanities context, and know the elements of legal regulation and the constitutive principles of communication and telematic security.

One of these courses, Management and preservation of digital documents (University of Calabria), prepares students for professions in public administration such as head of document management, workflows, and archives, IT protocol, or digital document preservation. Other courses focus on mediation between the worlds of traditional knowledge (texts in verbal/linguistic format, implicit knowledge) and digital knowledge (Digital and public humanities disciplines at $\mathrm{Ca}$ '

\footnotetext{
https://corsi.unibo.it/2cycle/DigitalHumanitiesKnowledge , June 23,
} 2021
Foscari, Venice and Text Sciences for the digital professions at the University of Catania) promoting the enhancement and dissemination of cultural content with a focus on training experts in public humanities. More recent training courses (e.g., Masters in Digital humanities and digital knowledge at the University of Bologna) teach skills for governing the entire supply chain of knowledge in the humanities: production, conservation, treatment, dissemination, and use of resources. These programs and courses emphasize the complex representation of knowledge, both formal and informal, which characterizes a modern model of the humanities.

DH education in the US differs from the EU. While digital literacy initiatives and resources exist for youth and adults at the federal and state levels, ${ }^{\dagger}$ educational policies related to digital literacy at the national level are absent, leading to inconsistencies that make it challenging to establish core requirements in $\mathrm{DH}$ education and training. A recent survey of DH programs in Anglophone countries (Sula et al., 2017), reveals variation in DH education foci (e.g., generalized DH, DH computing), program type (e.g., certificate, degree), and approach (fixed vs. agile) (Richards-Rissetto and Wisnicki, in print). While degrees in DH are offered, most educational programs comprise specializations, minors, concentrations, and certificates. As for $\mathrm{DCH}$, there are no degree programs in the US, and formalized programs, such as the Center for Advanced Spatial Technologies (CAST), University of Arkansas, ${ }^{\ddagger}$ are almost absent. In part, the lack of DCH degree programs and standardized pedagogical learning objectives stems from debates about what digital humanities is, as well as from disciplinary diversity (Gold, 2011).

However, DCH education is growing in the US. New courses, field schools, and specializations are particularly associated with digital archaeology, history, and/or library sciences and museum studies. For example, John Hopkins University offers an MA combining cultural heritage management with a Certificate in Digital Curation emphasizing archival methods. In contrast, digital archaeology programs typically emphasize field methods such as terrestrial and aerial laser scanning and photogrammetry, and other technical skills such as Geographic Information Systems. DCH courses range from introductory to advanced, with diverse foci, and a lack of common pedagogical standards. While organizations, institutions, and funding agencies are increasingly focused on DH and DCH pedagogy (Hirsch, 2011) and curriculum development (Locke, 2017), DCH education in the EU is more comprehensive, with more concrete efforts at standardizing competencies than in the US.

\section{CORE CURRICULA AND COMPETENCIES}

Core curricula as an overarching body of knowledge and competencies in a specific domain sum up conditions for learners, learning processes, and outcomes, and therefore define requirements for education. They record competencies for students in several sectors (subject-specific, social, etc.) and show the content of modules and their objectives. Furthermore, they point out organizational aspects and offer methods for university teachers to design courses that achieve desired learning outcomes. These outcomes include appropriate digitization processes related to teaching, learning, and curriculum development. Within $\mathrm{DH}$ and $\mathrm{DCH}$, emerging methodological and technical changes continue to greatly impact

\footnotetext{
${ }^{\dagger}$ e.g., https://incs.ed.gov/state-resources/federal-initiatives/digital-

literacy, June 23, 2021.
}

$\ddagger$ https://cast.uark.edu/, July 15th, 2021. 
the development of core curricula (Schulz, 2018). In particular, the wide array of digitization techniques require transformations not only in digital content but also in teaching digital pedagogy and curricular-based digital skills (Grünewald, 2020).

\section{Data Literacy}

Data literacy is defined as the ability to handle data in an organized manner, use it consciously, and question it in context (Schüller et al., 2019). This definition comprises competencies regarding the collection, exploration, management, analysis, and visualization of data but also to its interpretation, contextualization, evaluation, and application. Data literacy is a major prerequisite for scientific work and should therefore be a fundamental part of the training of all university students from an early stage. In recent years, universities have increasingly implemented data literacy courses and programs, but with different organizational structures and thematic foci.

One well-recognized example from the US is the course Data8: Foundations of Data Science at the University of California, Berkeley which started in 2017.* This course introduces entrylevel students from all disciplines to programming and statistics to work hands-on with real-life data. While universities in Germany have implemented data literacy in curricula in various ways, most programs encompass centrally organised, interdisciplinary courses intended for early-stage students. Adhering to recommendations from several studies on data literacy education (Arbeitsgruppe Curriculum 4.0, 2018; Gesellschaft für Informatik, 2018; Heidrich et al., 2018; Ridsdale et al., 2015), these courses typically include hands-on work with data similar to Data8. The programs often use lectures to raise awareness and give students an overview of the different aspects of data literacy. Complementary online courses or exercises may be used to provide additional information. More extensive modules (5-10 ECTS) on data literacy are less commonly used as a starting point. Main topics include programming, the basics of computer science, statistics, research data management, and ethical aspects of the work with data, as well as topics related to the application and the social impact of data and digitalization. Programming is a mandatory part of some of the data literacy programs. Other topics are highly dependent on the departments involved in organizing the respective programs. Several of the programs offer multiple levels so that the entrance threshold is low, but interested students can extend their data handling skills. Courses to achieve higher levels can either be specific and centrally organized (often in the form of workshops, training, or project-based courses) or students can select from a range of topics. Most programs award certificates for successful participation. In many cases, credit points from courses in the certificate programs can be used for the actual study program, which generates an additional incentive for students to participate in the certificate course and makes it attractive for students who are not required to complete a data literacy program.

Apart from creating special courses, many data literacy projects support lecturers in teaching data literacy competencies in their courses. Thus, the respective data literacy skill is directly connected to discipline-specific topics and students do not have to expend any additional effort.

\section{Digital Humanities}

Researchers have attempted to sum up and categorize DH programs, syllabi, and core topics. Sahle (2013) summarizes as main areas of study programs within digital society, culture, and science: (1), special research field areas (2), theories, methods and questions addressing them (3), digital transformation and tools (4), and resources for single research fields. (Sula et al., 2017) specify topics like enrichment, capture, and storage as prevalent in European programs, and meta-activities like project management and creation (designing, programming, writing) as special features in Anglophone programs.

These approaches also mention the importance of teaching content, methods, and skills in combination with practical formats like case studies, projects, or evaluation (Sahle, 2013). The latter is linked to project-based-learning (cf. Kröber and Münster, 2014) that is common in DH, which foster student creativity, problem-solving skills, collaboration, and independent learning (Spiro, 2011).

Core competencies in DH include research skills (e.g., information research and management), foreign language skills, general humanities methods, and specialist DH methods (Sahle, 2013). Analytical skills stem from the fields of ICT, data management, programming, digital editions, statistics, or technologies for creating websites (Schulz, 2018). DH courses therefore address the width of humanities research data, as well as their manipulation and modeling, handling, presentation, and interpretation (Grünewald, 2020). Additional, more advanced abilities in the DH curriculum incorporate modeling and analyzing questions and subsequently transforming them into technically supported solutions to provide a wider understanding of the research field, including practical applications (Sahle, 2013; Schulz, 2018). In those curricula, subject-specific knowledge concerning tangible and intangible heritage merges with knowledge of standards or tools that directly imply a connection to certain research questions or areas.

\section{Digital Cultural Heritage}

Numerous professional disciplines are engaged with cultural heritage and its digitization. Consequently, various and highly differing skills and competencies are needed, which has drastically changed in the digital age. A spectrum of DCH competencies comprises digital data curation, communication, and tool skills (Van Lakerveld et al., 2017). Although digital competencies are essential for heritage professionals at all career stages (Münster, 2019), training in digital heritage is still mostly provided through academic courses and curricula.

How is the situation in related fields? Competencies in cultural heritage education are described in several publications - most recently (Jagielska-Burduk and Stec, 2019), previously in (Chen et al., 2012) and by (Tammaro, 2017). Existing programs encompass topics about certain cultural artifacts, implementation in organizations and institutions, and technical research, use and publishing requirements (e.g., Leuven University, 2021). The latter include producing digital knowledge, analyzing and visualizing, and management (e.g., University of York, 2021). Concerning Digital archaeology, the International Campus of the Spanish Society of Virtual Archaeology, the Virtual Archaeology International Network, INNOVA, and 18 research groups from 14 universities (SEAV, 2012) has created a core curriculum for Spanish universities. A similar curriculum has been developed for digital curation (cf. Sabharwal, 2015) and investigated within the DigCurV Curriculum Framework (Cushing and Shankar,

\footnotetext{
"http://data8.org/, June 23, 2021.
} 
2019; Engelhardt, 2012). Although these frameworks target similar sets of competencies, they do not focus directly on DCH.

\section{Current DCH Courses}

Within Europe there are several opportunities to study digital heritage. For this article, options at bachelor's, master's, and doctoral level were examined using study portals - the three European platforms* within a partnership with institutions like the EC, DAAD, British Council, and UNESCO Institute for Lifelong Learning that provide prospective students from all over the world a curated review of study courses. For DCH, we do not claim that these results are complete but sketch an overview of possibilities for studying DCH in Europe. ${ }^{\dagger}$ More than half of the DCH education options in Europe comprise a master's degree (a total of BA: 119, MA: 136, PhD: 12). One possible reason for this could be the strong orientation toward research in heritage fields combined with digitally based infrastructures. As (Busch, 2020) points out, digital methods are primarily used in research settings, which is more relevant at master's level than in bachelor's programs (Fig. 1).

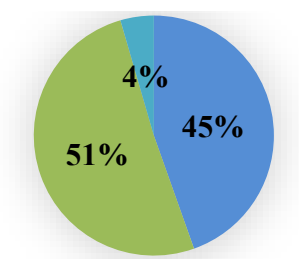

$$
\begin{aligned}
& \text { Bachelor } \\
& \text { Master } \\
& \text { PhD }
\end{aligned}
$$

Figure 1. Percentage of bachelor's, master's, and doctoral programs in DCH in Europe.

The countries in Europe $\$$ where DCH or related subjects are studied are Austria, France, Greece, Hungary, Ireland, Italy, the Netherlands, Poland, Russia, Slovakia, Spain, Sweden, Switzerland, Turkey, and the UK. The UK offers the largest number of $\mathrm{DCH}$ programs and is unique in that the majority are at the bachelor's rather than the master's level (cf. Fig. 2). In European countries, bachelor's programs are minimal or unavailable (e.g., Sweden or the Netherlands).

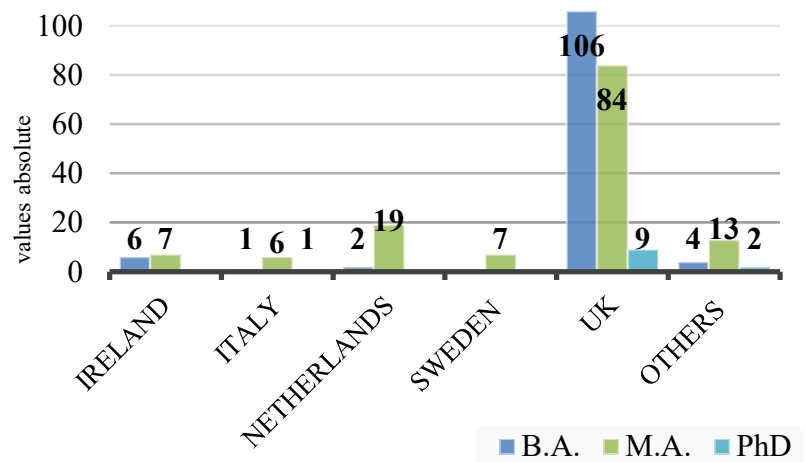

Figure 2. Locations in Europe to study DCH

At all levels, DCH is mostly connected to humanities disciplines (total 141); arts, design, and architecture (total 83); and social sciences (total 79). In addition, applied sciences, business management, computer science, and IT, hospitality, leisure and

\footnotetext{
${ }^{*}$ https://www.bachelorsportal.com, https://www.mastersportal.com, https://www.phdportal.com, July 5, 2021.

† The search term at all 3 portals was: "digital heritage". For comparison: "cultural heritage" attained 555 mentions for bachelor's studies and 585 mentions for master's studies in Europe.
}

sports as well as journalism and media are relevant subdisciplines where DHC is assigned (Fig. 3).

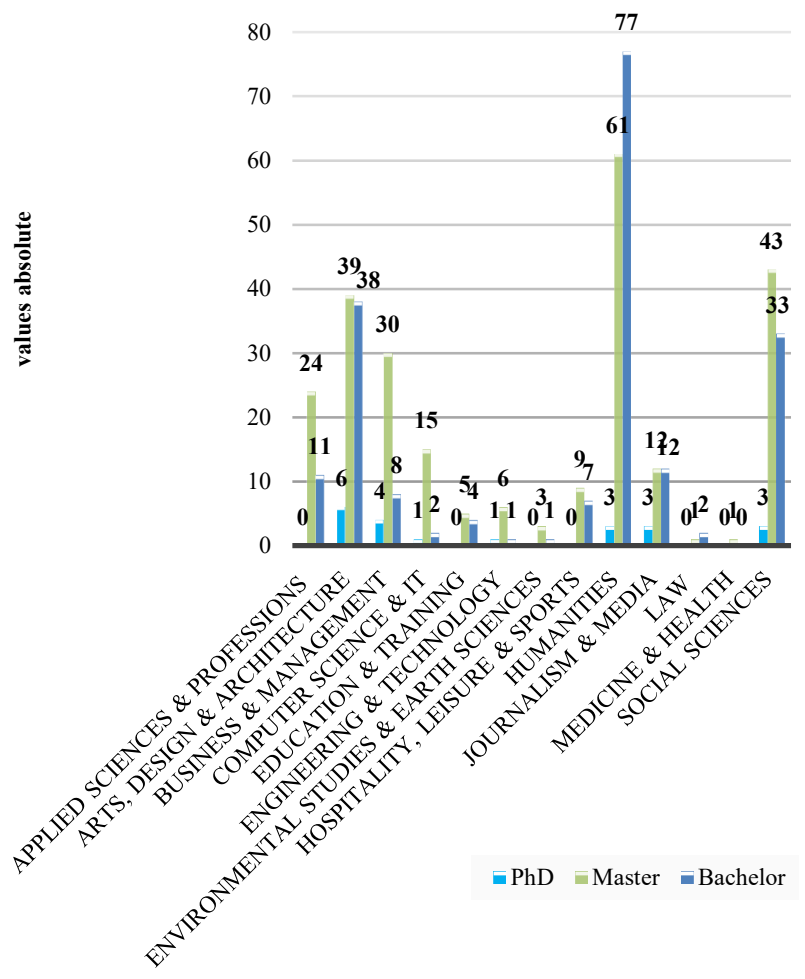

Figure 3. Levels and disciplines of DCH studies in Europe

In the next section this article will have a closer look on the three domains from which where the largest number of DCH courses originate. For DCH courses related to the humanities, the most frequent discipline is history, specifically modern and ancient history. In the language-related fields, language and literature studies and linguistics are the most represented disciplines (Fig. 4).

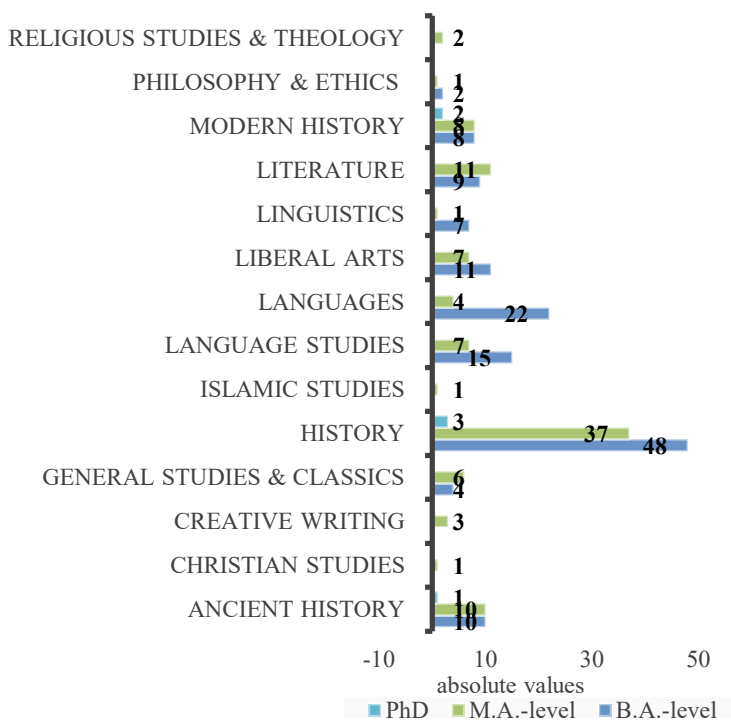

Figure 4. Domains of DCH in humanities programs

\footnotetext{
For this summary the geographical definition of Europe was used and
} Turkey and Russia included in the survey. 


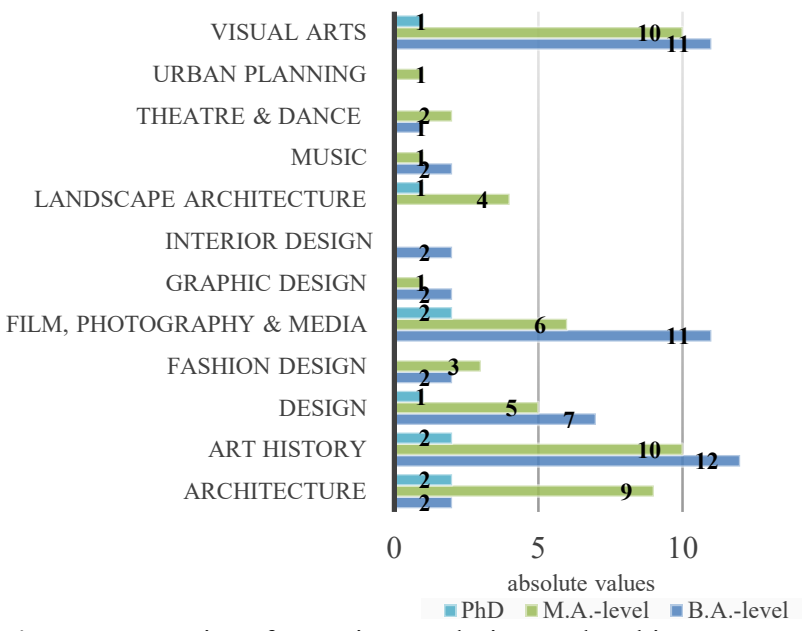

Figure 5. Domains of DCH in arts, design, and architecture programs

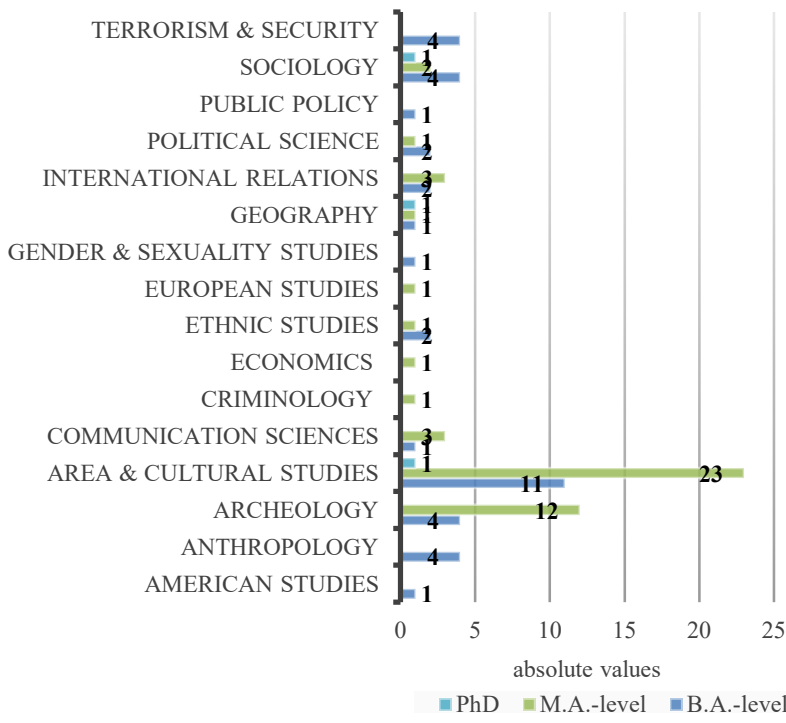

Figure 6. Domains of DCH in a social sciences program

Within the domain of arts, design and architecture, visual arts, film, photography, and media, DCH courses primarily relate to art history, architecture, and design (Fig. 5). In the context of social sciences DCH courses focus on urban and cultural studies and archaeology (Fig. 6). With regards to the different types of cultural heritage, European DCH programs mostly focus on tangible heritage, that is, artifacts, objects, images, and texts. Correspondingly fewer DCH programs focus on intangible, natural, or born digital heritage, including video games, music, theater, dance, religion, or spirituality.

\section{INNOVATIVE FORMATS}

Research-based teaching formats encourage learner participation and offer real-world learning opportunities (Brew and Saunders 2020). In recent years, digitally based teaching and learning formats continued to expand to all fields of study (Keengwe and Kidd, 2010). In DH and DCH, students encounter diverse range of formats. On the one hand, self-study formats are becoming a popular way to teach students DH and DCH skills for research purposes. ${ }^{*}$ On the other hand, courses for DH and DCH educators are offered to widen their specific teaching skills via digital formats. ${ }^{\dagger}$ Self-study for both students and educators is frequently based on wikis, blogs, and text, audio, or video lectures. Selfstudy material can stand alone or become part of teacher-driven DH and DCH courses (e.g., Münster et al., 2021; Openculture, 2021; PARTHENOS, 2020; Volk et al., 2019).

Tutorials are becoming increasingly popular as a self-study format. They are expected to become one of the most used techniques in education (MMB, 2020) because they provide theoretical and practical information that can often be archived for future needs (Bergert et al., 2018). In DH and DCH education, screencasts are often used to convey digital methods and the use of software (e.g., forText). ${ }^{*}$ They employ step-by-step visualization of applications and software tools to provide students with practical instructions that are embedded in the processing of specific questions and research problems. One example is the Digital4Humanities project $\$$ coordinated by Friedrich Schiller University Jena and supported by the Association of Digital Humanities in the German speaking countries. In the project, researchers from eight German and US universities are investigating the use of video tutorials for learning digital research methods in a self-directed way. Various tutorials have been created. Each tutorial comprises the theoretical aspects of a specific research method, explains the relevant methods or tools, and implements them in a practically oriented research context. The tutorials also show students how to handle the software tools on a step-by-step base. One objective of the project is to make the results available to other researchers, lecturers, or educators that want to create self-study tutorials. Another objective is to evaluate the tutorials with lecturers and learners to retrieve empirically based information about this selfstudy format.

While video tutorials address students in an active and inclusive manner and enable informal education, various formats are used to enhance formal education. One setting originally employed in secondary schools (King, 1993) and subsequently in universities (Spannagel, 2010) is the flipped or inverted classroom. In this setting, the learning phases are swapped. Students first learn individually and then come together with the teacher and peers for group learning. Class time is used for active problem-based learning and practice activities (Love et al., 2014). In fully digitally based settings, individual and group learning take place virtually. A digital approach opens new avenues to connect the inverted classroom with other approaches such as cooperative or collaborative learning (eg. Kopp and Mandl, 2006) in virtual environments. A recent survey showed that in fully digital settings the flipped classroom approach can have a positive effect on students' learning, attention, and evaluation of learning (Tang et al., 2020). In DH and DCH education another benefit of such settings is virtual collaborations at national and international levels. The close connection between education, research, and professional tasks (Sonntag, 2021) is also relevant for DH and DCH. Collaborative formats using problem-based learning (PBL) (Barrows, 1996) promote active engagement with the learning material, which helps learners to remember concepts and skills and promotes problem-solving competencies (Adobe, 2021). PBL is carried out in small tutorial groups under supervision and engages

\footnotetext{
$\S$ https://www.gw.uni-

jena.de/fakult $\% \mathrm{C} 3 \% \mathrm{~A} 4 \mathrm{t} /$ juniorprofessur $+\mathrm{f} \% \mathrm{C} 3 \% \mathrm{BCr}+$ digital+humaniti es+(bild_objekt)/projekt+digital4humanities, June 23, 2021.
}

\footnotetext{
e.g., DARIAH Teach, https://teach.dariah.eu, June 23, 2021.

$\dagger$ e.g., Europeana, https://europeana.eu, June 23, 2021.

* https://fortext.net/, July 6, 2021
} 
real-life challenges with hands-on training that transforms lecturers into coaches (for DCH, e.g., Maastricht University). ${ }^{*}$

\section{Virtual Learning Locations}

Furthermore, virtual learning locations are innovative teaching and learning environments. During COVID-19 a large number of cultural organizations and institutions virtually opened up to the public, including for educational purposes (cf. Network of European Museum Organisations, 2021). In this context, combined with the renaissance of virtual reality, there is a constantly increasing number of digital applications specifically focusing on DCH education via extended reality (XR) technologies. Their scope comprises virtual museum applications (as overview: ViMM WG 2.2, 2017), city tours (eg. Barthel et al., 2017), and cooperative 3D learning environments (eg. Radianti et al., 2020). These applications are designed to best ensure the transformative power of experiential learning and to enable integrated research and training activities. Through these solutions, it is possible to actively involve students, often resulting in faster learning, better retention, and better decisionmaking, as well as to provide researchers with advanced tools for study and analysis (Jing, 2019; Kencevski and Zhang, 2019).

\section{FUTURE PROSPECTS}

The current state of DH and DCH education, core curricula and competencies, and formats offer a foundation for future teaching and learning requirements.

\section{Management of Self-directed Learning}

Strong self-directed learning cannot thrive without organizational support (Traus et al., 2020). Students need to know how to manage learning in this way (University of Michigan, 2020). This approach could be implemented in curricula or at least in key qualifications, particularly important for nurturing scientific skills (Sahle, 2013) as a core competence for studying and research.

\section{Linking Primary, Secondary, and Higher Education}

Within several frameworks (Ferrari, 2013; Gesellschaft für Informatik, 2016; Redecker, 2017), it has already been pointed out that learning, working, and living are closely connected. Due to digitization, life is changing rapidly, and it is essential to evolve concepts of teaching in response to this phenomenon. As an example, the European Heritage Strategy for the 21st Century (Council of Europe, 2018) mentions the need to incorporate heritage education into school curricula. As such, virtual learning locations could connect schools, universities, and institutions or organizations and give galleries, libraries, archives, and museums the chance to interact with target groups at different educational stages.

\section{Lifelong Learning}

In addition to subject-specific and general key qualifications, some superior frameworks record overarching digital competencies (e.g., for lifelong learning, Council of the European Union, 2018). For example, the Italian national plan for the digitization of cultural heritage (Italian Ministry of Cultural Heritage and Activities and Tourism, 2017) aims to provide the multiple offices operating in cultural heritage with a model for managing digitization processes, to accelerate their development, and to facilitate access to the services offered. From this perspective, the plan should be understood as a management system of the digital ecosystem of cultural heritage that comprises general organizational and operational methods, definitions for tools, and methods of verification. To meet the needs that emerge from the launch of high-impact initiatives such as this Italian one, or to respond to the requests that come from operators and professionals in museums and public institutions, numerous transnational initiatives have been taken, such as those proposed by Una Europa Life Long Learning Certificates (4 ECTS). ${ }^{\dagger}$ They aim to provide a truly transnational learning environment where individual courses offered by the Una Europa partners $\$$ are mutually recognized as building blocks of a joint program, including lifelong learning in $\mathrm{DCH}$ as digital technologies applied to cultural heritage, management of digital data, and digital data services for study, research, and management.

\section{Citizen Science and Education}

Finally, citizen science approaches have found their way into the research and teaching of various university disciplines in recent years (Bonney et al., 2009), including DCH. In this context, knowledge transfers to citizen scientists creates particular didactic challenges (Roche, 2020). This is not least because the target or interested group for cultural heritage projects are often not digital natives and thus have to be addressed via other channels (Haumann and Smolarski, 2021). Knowledge transfer via digital citizen science activities nevertheless appears to be a promising approach, as public involvement in generating knowledge increases willingness to engage with cultural heritage. From a university perspective, getting an interested public from outside the academic institution involved in the research process is promising. This involvement can not only integrate previously inaccessible knowledge stocks, but also opens up new perspectives and interdisciplinary problem-solving approaches at the various levels of participation - from crowdsourcing to citizen science.

\section{ACKNOWLEDGMENTS}

Parts of the research described in this article were carried out in the project Digital4Humanities (German Federal Ministry of Education and Research, 16DHB3006). The authors would like to thank to Kate Sotejeff-Wilson and Anke Müller-Drabant for copyediting.

\section{REFERENCES}

Adobe, 2021. Creative Problem Solving in Schools. Essential skills today`s students need for jobs in tomorrow's age of automation.

Arbeitsgruppe Curriculum 4.0, 2018. Curriculumentwicklung und Kompetenzen für das digitale Zeitalter. Thesen und Empfehlungen der AG Curriculum 4.0 des Hochschulforum Digitalisierung. HFD position paper 39.

Barrows, H.S., 1996. Problem-Based Learning in Medicine and Beyond: A Brief Overview. New Directions for Teaching and Learning.

Barthel, K., Kröber, C., Friedrichs, K., Bruschke, J., Maiwald, F., Niebling, F., Münster, S., 2017. Enhancing Research And

\footnotetext{
${ }^{\dagger}$ https://www.una-europa.eu/initiatives/una-europa-life-long-learningcertificates, June 29, 2021.

* https://www.una-europa.eu/about, June 29, 2021.

* https://www.maastrichtuniversity.nl/education/why-um/problembased-learning, June 29, 2021.
} 
Education On Urban History By Using Mobile Technology, INTED 2017, Valencia.

Bergert, A., Lehmann, A., Halgasch, J., 2018. Potenziale videobasierter Inhalte an Hochschulen: Einsatzszenarien Trends - Erfolgskriterien, in: Bergert, A.e.a. (Ed.), Videocampus Sachsen - Machbarkeitsuntersuchung. Technische Universität Bergakademie Freiberg, Freiberg, pp. 63-82.

Bonney, R., Ballard, H., Jordan, R., McCallie, E., Phillips, T., Shirk, J., 2009. Public Participation in Scientific Research: Defining the Field and Assessing Its Potential for Informal Science Education. A CAISE Inquiry Group Report.

Busch, A., 2020. Curricula 4.0 aus Perspektive ausgewählter Disziplinen der Universitäten Göttingen und Mainz. In: S. Grünewald (Hrsg.). Studiengänge in der Digitalisierung: Baustelle Curriculumentwicklung. Hochschulforum Digitalisierung 52.

Chen, H.-L., Aparac-Jelušić, T., Brown, R., Hastings, S., 2012. Digital Content Creation: A Global View on Curriculum Design.

Corr, S., Marçal, E., Roche, N., 2019. Fostering innovation in heritage professions: the effect of the EYCH. SCIRESit 1.

Council of Europe, 2018. European Cultural Heritage Strategy fot the 21st Century.

Council of the European Union, 2018. Council Recommendation of 22 May 2018 on key competences for lifelong learning. Official Journal of the European Union.

Cushing, A.L., Shankar, K., 2019. Digital curation on a small island: a study of professional education and training needs in Ireland. Archives and Records 40, 146-163.

Directorate-General for Landscape, F.A., Architecture and Contemporary Art,, 2011. The Circular n. 31.

Eichhorn, Müller, Tillmann, 2017. Entwicklung eines Kompetenzrasters zur Erfassung „Digitaler Kompetenz“ von Hochschullehrenden, GMW 2017.

Engelhardt, C., 2012. The DigCurV Review of Training Needs in the Field of Digital Preservation and Curation: An Overview of the Main Findings.

European Commission, 2017. European Cultural Heritage Strategy for 21 st century.

European Commission, 2019a. The Digital Competence Framework 2.0.

European Commission, 2019b. Orientations towards the first Strategic Plan for Horizon Europe.

European Commission, 2021. European Competence Centre for digital preservation and conservation of cultural heritage and projects supporting digital innovation in schools.

European Committee for Standardization, 2014. European eCompetence Framework 3.0: A common European framework for ICT Professionals in all industry sectors.

Ferrari, A., 2013. DIGCOMP: A Framework for Developing and Understanding Digital Competence in Europe.

Gesellschaft für Informatik, 2016. Dagstuhl-Erklärung. Bildung in der digitalen vernetzten Welt, Dagstuhl.

Gesellschaft für Informatik, 2018. Data Literacy und Data Science Education: Digitale Kompetenzen in der
Hochschulausbildung. Policy Paper der Präsidiums-Task-Force „Data Science“ der Gesellschaft für Informatik e.V.in Zusammenarbeit mit Vertretern der Deutschen MathematikerVereinigunge.V., der Deutschen Physikalischen Gesellschafte.V. und der Gesell-schaft Deutscher Chemiker e.V.

Gold, M., 2011. Debates in the Digital Humanities. University of Minnesota.

Gottlieb, H., 2012. Designing Digital Heritage Competence Centers: A Swedish Model, in: Wu, S.W.P., Din, H.W.-h. (Eds.), Digital Heritage And Culture: Strategy And Implementation.

Grünewald, S., 2020. Studiengänge in der Digitalisierung: Baustelle Curriculumentwicklung. Hochschulforum Digitalisierung 52.

Haumann, A.-R., Smolarski, R., 2021. Digital project meets analog community. Expectations and experiences in a digital citizen science project on GDR history, Proceedings of Science 393, ACSC2020. https://doi.org/10.22323/1.393.0010.

Heidrich, J., Bauer, P., Krupka, D., 2018. Future Skills: Ansätze zur Vermittlung von Data Literacy in der Hochschulbildung. HFD position paper 37 .

Hirsch, B., 2011. Digital Humanities Pedogogy: Practices, Principles and Politics. Open Book Publishers.

Italian Ministry of Cultural Heritage and Activities and Tourism, 2017. Ministerial Decree n. 37/2017.

Italian Ministry of Universities and Scientific and Technology Research, 2004. Ministerial Decree n. 270/2004.

Italian Republic President, 2005. https://doi.org/10.1007/978981-13-2766-7_109.

Jagielska-Burduk, A., Stec, P., 2019. Council of Europe Cultural Heritage and Education Policy: Preserving Identity and Searching for a Common Core? Revista Electrónica Interuniversitaria de Formación del Profesorado 22, 1-12.

Jing, Y., 2019. VR, AR, and Wearable Technologies in Education: An Introduction, in: Y., Z., D., C. (Eds.), Handbook of Mobile Teaching and Learning. Springer, Singapore.

JISC, 2014. Strategic perspectives on digital literacies.

Keengwe, J., Kidd, T.T., 2010. Towards best practices in online learning and teaching in higher education. MERLOT Journal of Online Learning and Teaching, 6(2), 533-541.

Kencevski, K., Zhang, Y., 2019. VR and AR for Future Education, in: Y., Z., D., C. (Eds.), Handbook of Mobile Teaching and Learning. Springer, Singapore.

King, A., 1993. From sage on the stage to guide on the side. . College Teaching 41.

Kopp, B., Mandl, H., 2006. Selbst gesteuert kooperativ lernen mit neuen Medien. (Praxisbericht Nr. 33).

Kröber, C., Münster, S., 2014. An App for the Cathedral in Freiberg - An Interdisciplinary Project Seminar, in: Sampson, D.G., Spector, J.M., Ifenthaler, D., Isaias, P. (Eds.), Proceedings of the 11th International Conference on cognition and exploratory learning in digital age (CELDA 2014) Porto, Portugal. Oct. 25-27th 2014, pp. 270-274.

Leuven University, 2021. Digital Cultural Heritage. Activities, Topics discussed. 
Locke, B., 2017. Digital Humanities Pedagogy as Essential Liberal Education: A Framework for Curriculum Development. DHQ: Digital Humanities Quarterly 11, 116-123.

Love, B., Hodge, A., Grandgenett, N., Swift, A.W., 2014. Student learning and perceptions in a flipped linear algebra course. International Journal of Mathematical Education in Science and Technology 45, 317-324.

MMB, 2020. Weiterbildung und Digitales Lernen heute und in drei Jahren. Ergebnisse der 14. Trendstudie „mmb Learning Delphi“

Münster, S., 2019. Digital Cultural Heritage as Scholarly Field Topics, Researchers and Perspectives from a bibliometric point of view. Journal of Computing and Cultural Heritage 12, 22-49.

Münster, S., Apollonio, F., Bell, P., Kuroczynski, P., Lenardo, I.D., Rinaudo, F., Tamborrino, R., 2019. Digital Heritage meets Digital Humanities. ISPRS Archives XLII-2/W15, 813-820.

Münster, S., Kuroczyński, P., Fritsche, K., Barbosa, M.D., 2021. Virtuelle Akademie zur digitalen 3D-Rekonstruktion, DHd Annual Conference 2021.

Network of European Museum Organisations, 2021. Follow-up Survey on the impact of the COVID-19 pandemic on museums in Europe - Final Report.

Openculture, 2021. Free online courses Humanities and Social Sciences.

PARTHENOS, 2020. Training modules.

Radianti, J., Majchrzak, T.A., Fromm, J., Wohlgenannt, I., 2020. A systematic review of immersive virtual reality applications for higher education: Design elements, lessons learned, and research agenda. Computers \& Education 147, 103778.

Redecker, C., 2017. European Framework for the Digital Competence of Educators: DigCompEdu.

Richards-Rissetto, H., Wisnicki, A., in print. Building an Effective Digital Humanities Graduate Program, in: Appleford, S., Hankins, G., Lank, A. (Eds.), The Digital Futures of Graduate Study in the Humanities: Debates in the Digital Humanities Series. University of Minnesota Press.

Ridsdale, C., Rothwell, J., Smit, M., Ali-Hassan, H., Bliemel, M., Irvine, D., Kelley, D., Matwin, S., Wuetherick, B., 2015. Strategies and Best Practices for Data Literacy Education Knowledge Synthesis Report.

Risam, R., 2016. Other worlds, other DHs: Notes towards a DH accent. Digital Scholarship in the Humanities 32, 377-384.

Roche, J.e.a., 2020. Citizen Science, Education, and Learning: Challenges and Opportunities. Frontiers in Sociology 5.

Roche, N., Hurley, A., Limburg, A., Galán Pérez, A., Gunthorpe, K., 2019. Fostering Cooperation in The European Union on Skills, Training and Knowledge Transfer in Cultural Heritage Professions. Report of the OMC (Open Method of Coordination) Working Group of Member States' Experts. Publications Office of the European Union, Luxembourg.

Sabharwal, A., 2015. Digital curation in the digital humanities: Preserving and promoting archival and special collections. New York, NY: Chandos Publishing.
Sahle, P., 2013. Auf dem Weg zu einem Kern- und Referenzcurriculum der Digital Humanities. Georg-AugustUniversität Göttingen, Göttingen.

Schüller, K., Busch, P., Hindinger, C., 2019. Future Skills: Ein Framework für Data Literacy. HFD position paper 47.

Schulz, J., 2018. Auf dem Weg zu einem DH-Curriculum Digital Humanities in den Geschichts- und Kunstwissenschaften an der LMU Munich, in: Klinke, H. (Ed.), \#DigiCampus. Digitale Forschung und Lehre in den Geisteswissenschaften. Universitaetsbibliothek der Ludwig-Maximilians-Universit?t, Munich, pp. 77-101.

SEAV, 2012. Máster y Experto en Arqueología y Patrimonio Virtual.

Sonntag, R., 2021. So geht Lehre heute -2 Hochschulen, 1 gemeinsames virtuelles Modul.

Spannagel, C., 2010. Math for the Masses. Youtube-Chanel. https://www.youtube.com/user/pharithmetik/featured (12 June 2021). .

Spiro, L., 2011. Knowing and Doing: Understanding the Digital Humanities Curriculum. Stanford University.

Sula, C.A., Hackney, S.E., Cunningham, P., 2017. A Survey of Digital Humanities Programs. Journal of Interactive Technology \& Pedagogy.

Tammaro, A.M., 2017. New Profiles, New Skills, New Education for Digital Heritage Professionals: European Spotlight on Competency-Based System. International Information \& Library Review 49, 290-296.

Tang, T., Abuhmaid, A.T., Olaimat, M., Oudat, D.M., Aldhaeebi, M., Bamanger, E., 2020. Efficiency of flipped classroom with online-based teaching under COVID-19. Interactive Learning Environments.

Traus, A., Höffken, K., Thomas, S., Mangold, K., Schröer, W., 2020. Stu.diCo - Studieren digital in Zeiten von Corona.

UNESCO, 1989. Draft Medium Term Plan 1990-1995.

UNESCO, 2018. Concept of Digital Heritage.

University of Michigan, 2020. Adjusting your study habits during COVID.

University of York, 2021. MSc Digital Heritage. Curate heritage for a digital future.

Van Lakerveld, J.A., Vroonhof, P., Broek, S., Stoutjesdijk, F.D., van Loo, S.B., 2017. Skills, training and knowledge transfer: Traditional and emerging heritage professions. An exploration. Plato, Ockham, Panteia, Leiden.

ViMM WG 2.2, 2017. Meaningful Content connected to the Real World (Report).

Volk, M., Clematide, S., Bubenhofer, N., 2019. Sprachtechnologien in den Digital Humanities - MOOC. 